\title{
Estudos Sobre Educação Bilíngüe e Escolarização em Contextos de Minorias LingüIsticas no BrasiL * **
}

(Studies on bilingual education and schooling in Brazilian contexts of linguistic minorities)

\section{Marilda C. CaValcanti (UNICAMP)}

ABSTRACT: This paper aims at presenting a state-of-the-art of a subarea in Applied Linguistics, i.e., bilingual education studies in Brazil or yet education in bilingual settings such as indigenous communities, immigrant, frontier and deaf communities. These settings usually have more than two languages in use as well as language varieties. The paper shows a sociolinguistic panorama of the country and of the studies about education in linguistic minority contexts and draws implications for teacher education and language diversity.

KEY WoRDs: Linguistic Minorities; Multilingualism; Multiculturalism; Bilingual Educatiom; Bidialectal Settings.

PaLAVRas-Chave: Minorias Lingüísticas; Multilingüismo; Multiculturalismo; Educação Bilíngüe; Contextos Bidialetais.

Em comparação com outras subáreas da Lingüística Aplicada ${ }^{1}$, por exemplo, ensino-aprendizagem de línguas (materna/estrangeira) e tradução, os estudos sobre interação em contextos bi/multilíngües no Brasil são recentes. Não completaram ainda uma década e, por enquanto, constituem área de concentração em somente um programa de pós-graduação ${ }^{2} \mathrm{em}$ LA no país. Como se verá a seguir, isso não significa dizer que não existam estudos sobre

\footnotetext{
* Agradeço ao CNPq (520616/95-2) pelo auxílio que tornou possível a continuidade da pesquisa, base deste texto. Agradeço também a FAPESP (1996/4443-7) pelo auxílio no período 1997-1999 dentro do Acordo CNPq-Fapesp. O título dos projetos aos quais faço referência no texto são: Escolas da Floresta (CNPq 1995-97, Fapesp 1997-1999), O índio e a escola (CNPq 1997-99), e Vozes na Escola: Cultura e identidade em contextos sociolingüisticamente complexos (CNPq 1999-2001)

** Uma nota de agradecimento a A.L.César pela leitura de versão preliminar do texto e pela discussão decorrente.

${ }^{1}$ A Lingüística Aplicada como área de domínio próprio que tem pontos em comum, mas que difere da Lingüística e dela não depende em seus estudos, tem seu fortalecimento no meio da década de 80 com a abertura de novos programas de pós-graduação em Lingüística Aplicada. O primeiro programa de LA na PUC-SP é do início da década de 70. A Associação de Lingüística Aplicada do Brasil (ALAB) foi fundada em 1990.

${ }^{2}$ PPGLA/Unicamp.
} 
educação bilíngüe e sobre educação em contextos bi/multilíngües em outros programas. É importante observar que não estou me propondo a fazer aqui um trabalho exaustivo, mas apresentar contextos bi/multilíngües de minorias para que o mapa da educação nesses cenários seja desvelado, venha à superfície e possa ter visibilidade.

Observe-se que utilizo a expressão educação ou escolarização ${ }^{3}$ em contextos bi/multilíngües ${ }^{4}$ juntamente com o termo educação bilíngüe ${ }^{5}$ (Vide Hornberger, 1991, Freeman, 1998, Hamel, 1989, Garcia \& Baker, 1995) porque os contextos que vou focalizar podem ou não apresentar casos de educação bilíngüe propriamente dita. São, no entanto, cenários onde mais de uma língua é falada e não necessariamente é escrita. São cenários fortes em tradição oral.

O texto está organizado em três partes. Na primeira, focalizo o cenário sociolingüístico brasileiro e, na segunda, os estudos sobre educação em cenários bilíngüe/multilíngües e sobre o bilingüismo de minorias lingüísticas. Na terceira, dentro de uma tradição da Lingüística Aplicada de voltar à pratica, visando a um levantamento de implicações, busco estabelecer relações entre

${ }^{3}$ Ver também Cavalcanti (1998a e b).

${ }^{2}$ A reflexão que aqui faço tem como base projetos de pesquisa de cunho etnográfico que desenvolvi com uma equipe, primeiramente no contexto de educação escolar indígena e, a partir deste ano, em contextos bi/multillíngües de minorias. Baseia-se também na orientação de projetos de pesquisa visando a dissertações de mestrado e tese de doutorado. Mais especificamente, a discussão foi originada no desenvolvimento de dois projetos de pesquisa (Cavalcanti, 1995,1997), ambos com foco no contexto indígena assim como na orientação de trabalhos (Maher, 1990, 1996, Mendes, 1995, e em andamento, César, em andamento, e Freitas, em andamento), e também no trabalho de orientação de pesquisa nos contextos imigrantes (Jung, 1997, Takasu, 1999, Pereira, 1999) e de fronteira (Martins, em andamento). Esses trabalhos deram origem a um terceiro projeto de pesquisa (Cavalcanti, 1999c) que focaliza contextos sociolingüisticamente complexos sejam eles indígenas, imigrantes ou de fronteira. Em todos eles, as escolas focalizadas apresentam um cenário sociolínguisticamente complexo, uma vez que nas comunidades envolventes mais de uma língua e/ou mais de uma variedade lingüística são faladas.

${ }^{5}$ Em sua revisão das tipologias existentes sobre educação bilíngüe, Hornberger (1991) apresenta três modelos: de transição, de manutenção e de enriquecimento. O modelo de transição que se concretiza em programas de transição vê a língua como um problema a ser resolvido e visa a chegar à língua-alvo. A primeira língua do aluno ( a língua da comunidade) serve de ponte para a língua dominante. O modelo de manutenção, também concretizado em vários tipos de programas de manutenção, embora considere a língua da comunidade como direito, pode, em última instância, servir de transição para a língua da sociedade dominante. O modelo de enriquecimento - a língua como recurso (não somente para os alunos de comunidades minoritárias mas também para os alunos que são parte da sociedade dominante) - aparece em programas tais como: de imersão, de línguas de herança imigratória, de duas línguas, de imersão bilíngüe, de mão dupla. (Ver também Freeman, 1998.) 
o cenário sociolingüístico apresentado e a formação de professores.

\section{O cenário sociolingüístico brasileiro}

Quem catequizou os índios foi o coronel do barranco, o proprietário fazendeiro que botava os outros no cativeiro... amarrava e açoitava (...) $e$ amedrontou eles prá não falarem a língua ... prá desmoralizar ele botou o nome na língua "gíria".

Profa. Manaitá (Railda Poyanawá) in Maher \& Cavalcanti (1995)

Não sei falar bem o português. Na minha língua sou doutor.

Prof. Joaquim Maná Kaxinawá6 (Anotações de campo do Projeto Escolas da Floresta, 1997)

\section{Aqui só se fala português. ${ }^{7}$}

Professora em escola localizada em comunidade imigrante alemã de zona rural. (Jung, 1997)

Apesar de falas como as que servem de epígrafe para esta seção, geralmente causa estranheza quando digo que minha área de pesquisa atual está relacionada a contextos bilíngües de minorias (Cavalcanti, 1999c e d) no Brasil. Isso talvez aconteça, porque, em primeiro lugar, existe um mito de monolingüismo no país (Cf. Bortoni, 1984, Cavalcanti, 1996a, Bagno, 1999). Esse mito é eficaz para apagar as minorias, isto é, as nações indígenas, as comunidades imigrantes e, por extensão, as maiorias tratadas como minorias, ou seja, as comunidades falantes de variedades desprestigiadas do português. Em segundo lugar, uma das razões para essa estranheza pode ser decorrente de o bilingüismo estar estereotipicamente relacionado às línguas de prestígio no que se convencionou denominar bilingüismo de elite ${ }^{8}$. Em terceiro lugar, esses contextos bilíngües de minorias são (tornados) invisíveis, portanto

${ }^{6}$ O Professor Maná sabe falar muito bem o português (regional e com marcas indígenas) e como argumenta bem... Sua língua primeira, de identidade indígena, é o Kaxinawá. Com o português escrito, a aproximação aconteceu em contexto escolar. Sua fala exemplifica um cenário bi/multilíngüe no país.

${ }^{7} \mathrm{Na}$ escola, há momentos em que se fala o português da comunidade (o "brasileiro"), uma variedade de alemão e se aprende o português escrito do livro didático.

${ }^{8}$ A expressão educação bilíngüe é, geralmente, mais conhecida por sua associação ao bilingüismo denominado de elite, ou seja, um bilingüismo de escolha, relacionado a línguas de prestígio tanto internacional como nacionalmente. As escolas bilíngües no Brasil (e em outros países), por exemplo, escola americana, escola francesa, tem na língua alvo seu (principal e, às vezes, único) meio de instrução independentemente da L1 do aluno. 
naturalizados, tanto por quem deles faz parte como pela sociedade envolvente, uma vez que as línguas faladas são de tradição oral, portanto estigmatizadas. A questão da invisibilidade será retomada na segunda parte.

Não é somente no Brasil que essa imagem de cenário monolíngüe predomina. Mesmo se tendo a informação de que o bilingüismo está presente em praticamente cada país do mundo - Grosjean (1982:vii) diz que cerca da metade da população mundial é bilíngüe - segundo Romaine (1995:9), é o monolingüismo que representa a norma, é o monolingüismo que é a base para os estudos lingüísticos. De fato, para a autora, o monolingüismo deveria ser tratado como caso especial, como desvio da norma, e o bilingüismo deveria representar a norma. Diz ainda a autora (Romaine, 1995:8): Há cerca de trinta vezes mais línguas do que há países. Isso implica a presença do bilingüismo em praticamente todos os países do mundo.

No Brasil, não se pode ignorar os contextos bilíngües de minorias, uma vez que no mapa do país pode-se localizar em uma pincelada não exaustiva: i. comunidades indígenas em quase todo o território, principalmente, na região norte e centro-oeste; ii. comunidades imigrantes (alemãs, italianas, japonesas, polonesas, ucranianas, etc) na região Sudeste e Sul, que mantém ou não sua língua de origem; iii. comunidades de brasileiros descendentes de imigrantes e de brasileiros não-descendentes de imigrantes em regiões de fronteira, em sua grande maioria, com países hispano-falantes. Além dessa classificação geográfica, quando se focalizam os contextos bilíngües não se pode esquecer das comunidades de surdos que, geralmente, são criadas em escolas/ instituições e que estão espalhadas pelo país. Todos ${ }^{9}$ esses contextos bilíngües são de alguma forma também "bidialetais", pois contemplam alguma variedade de baixo prestígio do português ou de outra língua lado a lado com a variedade de português convencionada como padrão.

Se estou focalizando contextos bilíngües, por que estou também me referindo a falantes de variedades consideradas de baixo prestígio do português do Brasil? A resposta é simples: nos estudos realizados (Vide Jung, 1997, Pereira, 1999, Maher, 1996, Cavalcanti, 1997b) os contextos bilíngües são sempre mais complexos do que parecem à primeira vista e essa complexidade passa pelas variedades do português. Em outras palavras, esses contextos

\footnotetext{
${ }^{9}$ Há ainda outras comunidades bilíngües como as de terreiros de candomblé que congregam brasileiros descendentes e não descendentes de africanos também apagadas do cenário sociolingüístico do país.
} 
bilíngües de minorias são também "bidialetais"10. De fato, a complexidade mencionada resulta em apresentar esses contextos como multilíngües e não somente bilíngües, dando o devido status às línguas (e não às variedades ou dialetos) falados por essas comunidades.

Contextos indígenas

Contextos indígenas

O universo indígena no Brasil hoje é pequeno, porém, extremamente rico e diverso no que concerne aos aspectos sociolingüísticos, sociohistóricos e socioculturais. É composto de aproximadamente (não há um levantamento preciso e oficial, cf. Cardoso de Oliveira, 1988:34) de 250.000 pessoas o que corresponde a menos de $0.2 \%$ da população do Brasil. Das cerca de 1300 línguas faladas pelos diversos grupos por volta de 1500, apenas 170 sobreviveram. Muitas dessas línguas têm pouquíssimos falantes. É importante observar que, por volta do ano de 1500 , a população indígena era aproximadamente de 5 milhões de pessoas e as línguas faladas eram cerca de 1300, de acordo com vários registros, inclusive Ribeiro (1995). A taxa de crescimento populacional, hoje, no entanto, e felizmente, é maior do que a população não-indígena: $4 \%$ ao ano.

Nos contextos acima descritos, há situações de manutenção, de perda e processos de "revitalização"11 da língua nativa. Os processos de "revitalização" podem ter um peso simbólico (Vide Maher, 1996), por exemplo, no material didático em língua indígena em uma comunidade onde não se fala/ ensina essa língua. Esse material, no entanto, simboliza a posse/a existência da língua. No caso do português falado pelos índios, é interessante observar que a língua de origem da comunidade, mesmo nos casos em que não é mais falada, por exemplo, na Comunidade Indígena Apurinã no Sudoeste do Amazonas, deixa sua marca (Ver Maher, 1996, 1998) na variedade de português que se torna a primeira língua. Maher utiliza o termo "português índio" para fazer referência a essa variedade do português falado. Outros autores (por exemplo, Grillo Guimarães, 1996) utilizam o termo "português étnico".

\footnotetext{
${ }^{10}$ Vide Bortoni (1998) sobre o continuum rural-urbano, o continuum de oralidade e letramento e continuum de monitoração estilística.

${ }^{11}$ Utilizo o termo revitalização entre aspas como forma de questionamento, uma vez que, dado o dinamismo de uma língua seria impossível revitalizá-la como foi no passado. Em outras palavras, o termo revitalização, que parece indicar a idéia de imutabilidade, necessita ser relexicalizado ou então mudado.
} 
Contextos de imigração

Tendo em vista que a imigração é apenas uma parte da história para os contextos atuais bilíngües/bidialetais, reporto-me a Ribeiro (1995:241):

$O$ contingente imigratório ${ }^{12}$ europeu integrado na população brasileira é avaliado em 5 milhões de pessoas, quatro quintas partes iguais entraram no país no último século. (...) [Esse contingente] é composto, principalmente, por 1,7 milhão de imigrantes portugueses, que se vieram juntar aos povoadores dos primeiros séculos, tornados dominantes pela multiplicação operada através do caldeamento com índios e negros. Seguemse os italianos, com 1,6 milhão; os espanhóis, com 700 mil; os alemães, com mais de 250 mil; os japoneses, com cerca de 230 mil e outros contingentes menores, principalmente eslavos, introduzidos no Brasil sobretudo entre 1886 e 1930.

O país tem então como "raízes" os índios, os portugueses e os africanos. Nos índios temos os donos das terras, desalojados para que essas fossem doadas aos primeiros imigrantes ${ }^{13}$, os colonizadores portugueses. Com os índios desalojados, tentou-se escravizá-los. Não deu certo. Vem então da África, a mão de obra escrava, cerca de 6 milhões de pessoas (Ribeiro, 1995:228), para trabalho forçado nas terras "doadas" aos portugueses. Os imigrantes, que, curiosamente, sempre estão fora do tripé das "raízes" brasileiras, chegaram em maior número após a Abolição da Escravatura. Vieram, principalmente italianos e japoneses, substituir os africanos na agricultura, sonhando com a aquisição de terras. Ou seja, até 1836 o fluxo de imigração era de portugueses e africanos ${ }^{14}$. Entre 1836 e 1968, cerca de 5 a 7 milhões de imigrantes se instalaram na região Sul e Sudeste, especialmente em zonas rurais. É nessa época que chegam os alemães e também mais japoneses. Mais tarde, o governo brasileiro,

12 Os números apresentados por Ribeiro convergem com o quadro apresentado pela Folha de São Paulo em 13/07/97 para um período de 60 anos:1870-1868. Esses números indicam "cerca de de 5 milhões a 7 milhões" de imigrantes e "não incluem os africanos trazidos para o país como escravos": 1,76 milhão de portugueses, 1,62 milhão de italianos, 719 mil espanhóis, 257 mil alemães, 243 mil japoneses, 119 mil russos, 98 mil austríacos, 79 mil 'turcos', 54 mil poloneses, 50 mil franceses. "A maioria deles se instalou nas regiões Sul e Sudeste do país, onde a necessidade de mão-de-obra era mais forte, em especial para a agricultura".

${ }^{13}$ Usei o termo imigrante propositalmente. Esses primeiros portugueses não são vistos como tal, parecem ter um status superior como "donos/donatários" das terras.

${ }^{14}$ Há registros também de libaneses que chegaram já com os portugueses e se estabeleceram no comércio. 
através de intermediários europeus, apoiou um programa de incentivo à imigração através da venda de terras para agricultura. Dessas ondas imigratórias, temos hoje os descendentes de imigrantes ${ }^{15}$ africanos $^{16}$ que podem constituir uma maioria em algumas regiões do país (Vide César, 1995; César \& Silva, 1992) apesar de serem tratados como minorias. Os descendentes de imigrantes europeus ${ }^{17}$ (italianos, alemães, ucranianos, poloneses, holandeses, espanhóis, austríacos, russos, para nomear alguns) e asiáticos (japoneses, chineses) fazem parte da imigração antiga e estão principalmente no Sul e Sudeste do país. Como exemplo de imigração recente, pode-se citar os coreanos.

Ainda conforme Ribeiro (1995: 242):

Não ocorre no Brasil (...) nada parecido com o que sucedeu nos países rio-platenses, onde uma etnia original numericamente pequena foi submetida por massas de imigrantes que representando quatro quintos do total, imprimiram uma fisionomia nova, caracteristicamente européia, à sociedade

${ }^{15}$ Os africanos também não são vistos como imigrantes por razões diversas da explicação da nota anterior. Arrisco-me a dizer que a razão estaria mais relacionada a uma política de "branqueamento" do país através das contínuas levas de imigração européia. Dessa política, certamente, poderia fazer parte os apagamentos (propositais) existentes nas famílias brasileiras dos ascendentes negros e também índios em favor dos ascendentes imigrantes europeus.

${ }^{16}$ Conforme Ribeiro (op. cit.:114): Os negros do Brasil, trazidos principalmente da costa ocidental da África, foram capturados meio ao acaso nas centenas de povos tribais que falavam dialetos e línguas não inteligíveis uns aos outros. A África era, então, como ainda hoje o é, em larga medida, uma imensa Babel de línguas. Embora mais homogêneos no plano da cultura, os africanos variavam também largamente nessa esfera. Tudo isso fazia com que a uniformidade racial não correspondesse a uma unidade lingüístico-cultural, que ensejasse uma unificação, quando os negros se encontraram submetidos todos à escravidão. (...) Encontrando-se dispersos na terra nova, ao lado de outros, seus iguais na cor e na condição servil, mas diferentes na língua, na identificação tribal e freqüentemente hostis pelos referidos conflitos de origem, os negros foram compelidos a incorporar-se passivamente ao universo cultural da nova sociedade. E apesar das circunstâncias adversas, aprendem o português "para comunicar-se entre si."

${ }^{17}$ Brasililianistas, por exemplo, Lesser (1999, mencionado na Folha de São Paulo, 06/ 06/99, 5:7), levantam a hipótese da busca de embranquecimento do "sangue moreno brasileiro através da vinda de imigrantes brancos europeus". Já, de acordo com Nobles (no prelo, também parte da reportagem da Folha de São Paulo, 06/06/99, 5:8) aponta que o "censo tem ajudado a embranquecer" o país. Afirma que "o censo no Brasil tem sido uma disputa entre os que acham que o país é de maioria branca e os que defendem que somos um país de negros ou pelo menos de não-brancos. O pomo da discórdia, claro, é o mulato." 
e à cultura nacional, transfigurando-os de povos novos em povos transplantados. O Brasil nasce e cresce como povo novo, afirmando cada vez mais essa característica em sua configuração histórico-regional. $O$ assinalável no caso brasileiro é, por um lado, a desigualdade social, expressa racialmente na estratificação pela posição inferiorizada do negro e do mulato. E, por outro lado, a homogeneidade cultural básica, que transcende tanto as singularidades ecológicas regionais, bem como as marcas decorrentes da variedade de matrizes raciais, como as diferenças da proveniência cultural dos distintos contingentes.

Contextos de fronteira

Apesar da extensão da fronteira brasileira em contato/conflito ${ }^{18}$, primordialmente, com países hispano-falantes, não há muitos estudos sobre as comunidade de fronteiras. No caso da fronteira com o Uruguai talvez se tenha mais informação, como, por exemplo, os estudos citados ${ }^{19}$ em Trindade, Behares e Fonseca (1995) e desenvolvidos pela Universidad de la Republica/ Uruguai. Em relação às comunidades de fronteira com o Paraguai, há alguns estudos (Vide, por exemplo, Martins, 1996) que focalizam a movimentação de imigrantes brasileiros de ascendência alemã para a zona rural paraguaia próxima na fronteira com o Brasil. Há também estudos (Vide D’Angelis \& Mazzarolo) que discutem a migração brasileira para o Paraguai e que mostram a fronteira do lado brasileiro (Ver Santos, 1999).

Comunidades de surdos

De acordo com o Correio Braziliense (1997), dados da Organização Mundial da Saúde (OMS) indicam que "a deficiência auditiva afeta 10\% da população mundial". Conforme a mesma fonte, "no Brasil, estima-se que existam 15 milhões de pessoas com algum tipo de perda auditiva. Desses 350 mil são totalmente surdos". A população de surdos é, portanto, quantitativamente grande. No entanto, como acontece nos outros contextos focalizados, também aí há um apagamento, uma minimização de sua importância, que promove sua invisibilidade.

\footnotetext{
${ }^{18}$ Minha escolha pelo termo contato/conflito (lingüístico) está relacionada à discussão de vários autores, principalmente em relação à posição tomada a partir dos autodenominados sociolingüistas de periferia. O ponto da discussão que não há contato sem conflito, por exemplo, no caso da diglossia. (Ver Martin-Jones, s.d. e Hamel \& Sierra, 1995.)

${ }^{19}$ Elizaincín, Behares \& Barrios (1987), Elizaincín (1976), Behares(1982).
} 
Essas comunidades, que muitas vezes estão espalhadas, há muito reivindicam acesso à língua de sinais (LIBRAS). Já sofreram e ainda sofrem discriminações. Os estudos nessa área estão mais voltados para a descrição da Língua Brasileira de Sinais (LIBRAS) e para sua importância. Brito (por exemplo, 1993) tem uma contribuição importante para a área. Há projetos educacionais tentando levar os resultados dessas pesquisas para a prática (cf. Favorito, 1999) como é o caso do Instituto Nacional de Educação de Surdos (INES) no Rio de Janeiro. A meu ver, questões de bilingüismo e de bidialetalismo têm espaço potencial nesse contexto.

Contextos bidialetais/rurbanos

Essas comunidades, que constituem a maioria da população dentro e fora da escola, dentro e fora do sistema, "com fome de cidadania, salário, educação ..." (remetendo a um artigo de Herbert de Souza, publicado no Jornal do Brasil em 1993, não podem deixar de ser mencionadas porque sua(as) variedade(s) lingüística(s) é(são) diferente(s) do português visto como padrão.

A premissa é, portanto, que há uma maioria de contextos bidialetais nas escolas públicas brasileiras. Esses contextos são ou ignorados ou apagados (Ver, no entanto, os Parâmetros Curriculares Nacionais, e Bagno, 1997) e passam a impressão de cenários monolíngües. Para Romaine (1995), há, no entanto, heterogeneidade mesmo em comunidades consideradas monolíngües, uma vez que geralmente há variedades regionais, sociais e estilísticas dentro do que é considerado como "uma língua".

Utilizo aqui o termo bidialetal segundo Bortoni (1984), de forma a polemizálo e com vistas a depreender implicações para a formação de professores no país. Bidialetais são, por exemplo, as comunidades "rurbanas" (Cf. Bortoni, 1985) compostas por populações de origem rural que vivem na cidade e que falam alguma variedade estigmatizada ${ }^{20}$ de português. Essas comunidades constituem o que venho denominando "as maiorias tratadas como minorias.

Rajagopalan (1998:23) diz: ... quando se trata de distinguir entre categorias conceptuais nebulosas como "língua" e "dialeto, até os lingüistas se abstém

\footnotetext{
${ }^{20}$ Essas variedades tem nos traços descontínuos (Vide Bortoni-Ricardo, 1984) as marcas da estigmatização: muié, nóis fumu, nóis vinhemu. Esses traços convivem com traços graduais que já estão incorporados ao português padrão oral: os meninu, me dá.
} 
de estabelecer uma diferença. Para Wiley (1996:105): o termo "dialeto" (...) em seu uso popular carrega uma conotação subpadrão. (...) Embora alguns lingüistas façam objeção ao termo 'dialeto' por razões técnicas, a maioria acredita que é aplicável a todas as variedades da língua inclusive a padrão. Neste texto, poderia estar usando somente o termo "língua" como foi feito em Jung (1997), porém, optei por "bidialetal" para dramatizar a questão e por "bilíngüe" para chamar a atenção sobre cada um dos contextos focalizados, que em verdade, é multilíngüe e não apenas bilíngüe. No dois casos, como já apontei anteriormente, busco especificamente e deliberadamente trazer os termos para discussão.

A respeito da discussão sobre variedades lingüísticas, é importante ainda destacar, seguindo Cazden (1993:198), que:

todas as línguas são faladas em muitas variações - variações que tem um desenvolvimento histórico, são distribuídas de modo não-aleatório na sociedade, e são profundamente influenciadas por relações de poder tanto no cenário mais próximo (o contexto da situação) como na sociedade (o contexto cultural).

Para a imagem firmada de um país monolíngüe onde, além da língua dita padrão, sequer uma variedade de português é reconhecida, houve "contribuição" nos diferentes contextos focalizados. No caso dos falantes de variedades de baixo prestígio do português, o português falado é visto como "errado" e a questão era somente fazer com que aprendessem a "falar português direito" e tudo estava resolvido. No caso dos indígenas, a proibição de uso das línguas indígenas foi direta nos variados contextos: a língua indígena (qualquer que fosse) era "feia" - a denominação "gíria" não é gratuita - e ser índio era uma "vergonha" (cf., por exemplo, fala da Profa Manaitá no início desta seção). Não é preciso acrescentar mais nada para entender que esse foi um incentivo (de sucesso!) para a construção da baixo-estima da população indígena e do perigo de deslocamento das línguas indígenas. No caso dos africanos e seus descendentes, essa proibição, hoje esquecida e raramente mencionada nos livros didáticos de História, é parte, por exemplo, da invisibilidade da presença ${ }^{21}$ de termos das línguas africanas incorporados à Língua Portuguesa falada no Brasil. No caso das línguas de comunidades

\footnotetext{
${ }^{21}$ Há estudos sobre o assunto, principalmente na Bahia, porém não parece haver interesse e vontade política de dessiminação desse conhecimento.
} 
imigrantes, houve a proibição ${ }^{22}$, à época do governo Getúlio Vargas, de línguas estrangeiras dos países do Eixo nas escolas e comunidades. No caso dos surdos, estes, a princípio estavam confinados aos lares, e se estavam em comunidades estas eram silenciosas. Além disso, era comum ouvir-se o questionamento se a Língua dos Sinais constitui uma língua.

Educação bilíngüe no Brasil?

A partir do que foi exposto, depreende-se que o Brasil ${ }^{23}$ não reconhece e não encoraja o ensino bilíngüe no contexto de minorias lingüísticas. A exceção fica com as comunidades indígenas, que tem na Constituição de 88 o direito assegurado para a educação bilíngüe, mas que se não fosse pelo trabalho de indigenistas, de ONGs e, em menor escala, de grupos de pesquisa/ensino de universidades nada teria de concreto hoje.

Um parêntese é necessário, neste ponto, para lembrar que "somente em 1991 a educação indígena foi introduzida na constituição brasileira como sendo responsabilidade do governo" (Cavalcanti, 1996a). Em 1994 orientações escritas para uma política educacional indígena foram produzidas pelo Ministério da Educação (Ministério da Educação e Cultura, 1994). E em 1998, foi publicado o Referencial Curricular Nacional para Escolas Indígenas.

Deve-se observar também que as escolas em contexto indígena são um caso à parte. São oficialmente reconhecidas como escolas bilíngües e seus professores se autodenominam bilíngües. Nas etnias focalizadas no Acre, considerando o ponto de vista dos professores índios, a escola, que veio de fora, da sociedade dominante, é um conceito em construção. Mesmo considerando que nesse pequeno universo indígena no Brasil existe diversidade lingüística e diversidade de contato/conflito, o conceito de escola em construção não se aplica a todas as comunidades indígenas.

\footnotetext{
${ }^{22}$ De acordo com Kreutz (1994), essa proibição é parte de uma campanha de nacionalização do ensino, com início em 1918, desenvolvida pelo governo brasileiro de modo preventivo até 1938 e, a partir daí, de maneira ostensiva. Kreutz (: 48) aponta que para o governo "o perigo estava apenas nas escolas teuto-brasileiras ["indício seguro de resistência local antibrasileira"]. Entendia que a etnia italiana não oferecia problema neste sentido. [Também não ofereciam perigo as escolas nas comunidades dos imigrantes judeus, poloneses e japoneses porque eram pequenas (Kreutz: 47).] Sobre a questão da proibição nas comunidades imigrantes alemão, ver também Bärnert-Fürst (1989) e Pereira, (1999).

${ }^{23}$ Essa situação não é "privilégio" do cenário brasileiro. É comum em outros países, por exemplo, nos EUA, o não reconhecimento e o não encorajamento de ensino bilíngüe.(Ver Freeman, 1998)
} 
Nos Parâmetros Curriculares, no entanto, as questões aqui focalizadas são mencionadas, porém, não são elaboradas ou enfatizadas. E entre aparecer no documento e ser efetivamente parte da escola existe uma distância grande e essa distância passa pelos cursos de formação de professores assim como passa pelas decisões de políticas lingüísticas e educacionais. "A escola(rização) bilíngüe/bidialetal não faz [portanto ainda] parte da vida educacional brasileira" (Cavalcanti, 1999c:2). Em outras palavras, o bilingüismo de minorias e o bidialetalismo de maiorias, na prática, ainda está naturalizado como invisível (Cavalcanti, 1996b, 1997a).

As escolas em contexto indígena e na zona rural têm (ou tinham) em comum o fato de serem bi- ou multisseriadas. No contexto indígena continuam multisseriadas no Acre, no Xingu, mas em Minas Gerais, por exemplo, índios pataxó são levados para estudar em escolas seriadas na cidade mais próxima pela Prefeitura. De acordo com os professores indígenas do Acre, as classes multisseriadas favorecem o aprendizado em grupo: um aluno ensina o outro, parte integrante da pedagogia indígena.

Na zona rural essas classes estão em vias de extinção no Estado de São Paulo e no Estado do Paraná: os alunos são transportados às escolas na cidade mais próxima pela Prefeitura (Jung, 1998). Enquanto os contextos de bilingüismo na zona rural ficam aglutinados e até incentivam o bilingüismo (Jung, 1997), nas cidades ficam dispersos em salas de aula multiculturais tratadas como se fossem monoculturais e monolíngües. A resistência dos alunos a aprender e à escola é vista como parte de outros fatores e não como relacionada à diferença lingüístico-cultural ${ }^{24}$ (Jung, em andamento).

Nessas escolas localizadas em comunidades imigrantes, algumas contam com professores da própria ${ }^{25}$ comunidade. As escolas são oficialmente monolíngües, mas, em comunidades bilíngües, é natural que haja trânsito entre uma e outra língua e é isso que se viu na prática (Jung, 1997). É claro que há sempre o receio de o professor de não estar trabalhando de acordo com a

\footnotetext{
${ }^{24}$ A discussão do termo cultura não faz parte do escopo deste texto. O termo, aqui utilizado com base em De Certeau (1995), Erickson (1996, 1997) e Azcona (1993), carregado de imprecisão e polissemia, é parte tanto do cotidiano da rua como da academia.

${ }^{25}$ Âs vezes, professores da própria comunidade com o poder que a instituição lhes confere podem ser insensíveis às suas próprias origens. Outras vezes não: intuitivamente desenvolvem uma sensibilidade, quem sabe para compensar o problemas que eles próprios, como alunos, enfrentaram na escola (Ver Osborne, 1996, e Jung, 1997).
} 
Secretaria da Educação (cf. Jung, 1997, e Pereira, 1999) e há sempre uma afirmação sobre o português como sendo a única língua da escola. Tantos anos passados da proibição das línguas dos países do Eixo nas escolas e essa questão continua. A solução poderia vir dos supervisores de ensino, que deveriam ser sensíveis à diversidade lingüístico-cultural para poder orientar os professores. Reclamam esses supervisores ${ }^{26}$ sobre sua falta de conhecimento sobre o contexto em que atuam os professores. São, portanto, necessários $\operatorname{cursos}^{27}$ para formadores de professores e para agentes e técnicos de secretarias de educação e delegacias de ensino (ou similares) que estão em contato com esses professores. Essa sugestão ratifica a proposta constante do Referencial Curricular Nacional para as Escolas Indígenas.

Em outras palavras, a política lingüística de monolingüismo no Brasil (Cavalcanti, 1996b) é uma questão naturalizada, tornada natural. Para Wiley (1996:103): Apesar de sua recência [data de 1960] como uma área acadêmica, o planejamento lingüístico e a análise da política lingüística sempre existiram como atividades de estados e impérios, embora não explicitamente sob esses rótulos. E de novo essa não é uma questão isolada. Para Wiley (1996:105): Em sociedades onde a maioria da população é monolíngüe (...), há freqüentemente uma suposição subjacente de que o monolingüismo (...) representa um estado ideal natural, enquanto o multilingüismo representa um condição temporariamente anormal. No Brasil, a maioria da população é vista como monolíngüe, mas como apontado anteriormente, essa visão é artificial, porém extremamente eficaz para a imagem de estado ideal natural longe do "perigo" de qualquer condição temporariamente anormal proveniente de situações de bi/multilingüismo.

2. Os estudos sobre educação em contexto bilíngüe: a invisibilidade do bilingüismo e do "bidialetalismo"

A gente não fala bem nem o alemão nem o brasileiro.

Depoimento de morador de comunidade imigrante de zona rural (Pereira, 1999).

\footnotetext{
${ }^{26}$ Anotações realizadas durante o Seminário Estadual sobre o Currículo de Magistério Indígena. Participação (na elaboração e ) na apresentação das disciplinas de Línguas, Estudo Dirigido e Iniciação à Pesquisa. Rio Branco, Acre. 23 a 25/05/1996.

${ }^{27}$ A Comissão Pró-Índio do Acre estará responsável por um curso para técnicos e supervisores da Secretaria de Educação do Estado a partir do ano 2000.

${ }^{28} \mathrm{E}$ o contato (que às vezes se torna conflito nessas situações) com o português escrito foi na escola...
} 
Minha primeira língua é o japonês, a língua da minha famíla. Meu primeiro contato com o português ${ }^{28}$ foi com os empregados da fazenda [no interior de São Paulo]. (Takasu, 1999)

Há um ponto em comum entre os contextos apresentados sejam eles de comunidades indígenas, de comunidades de imigrantes e de fronteira: são de tradição oral. São também de tradição oral as comunidades rurais e rurbanas. As crianças (e adultos) dessas comunidades se deparam com uma lingua(gem) totalmente desconhecida na escola: o português escrito. Além disso, essas comunidades pertencem a minorias lingüísticas (muitas com terra própria como relatam Jung, 1997, Martins, 1996, Pereira, 1999a ) e falam mais de uma língua, apesar de não se reconhecerem e não serem reconhecidas como bilíngües. Houve um processo de naturalização da invisibilidade desse tipo de bilingüismo. Por exemplo, até há pouco tempo, os indígenas eram sempre apresentados no tempo passado nos livros didáticos como se não existissem mais; os imigrantes eram mencionados pela mídia somente em épocas festivas quando interessava mostrar que as comemorações eram realizadas de modo diferente, peculiar. As comunidades de fronteira e as comunidades de surdos não apareciam nem na mídia e muito menos nos livros didáticos. Em relação ao bidialetalismo, o "caipira", por exemplo, só aparece na mídia, de forma estigmatizada, durante o período de festas juninas.

Nos estudos realizados por Jung (1997) e por Pereira (1999) foi observado que nesses contextos há um sentimento de inferioridade em relação às línguas faladas devido a pelo menos dois fatores: a) as línguas faladas não são (d)escritas e como tal não são reconhecidas; b) a incidência de não escolarização dos integrantes adultos da comunidade. No caso das comunidades rurbanas (urbanas de origem rural), de tradição oral, a língua da escola também é diferente daquela falada em casa e na comunidade. Neste caso, no entanto, o foco não está nas minorias lingüísticas: são, na verdade, maiorias $^{29}$, porém com tratamento de minorias, que falam uma variedade de

\footnotetext{
${ }^{29}$ Ver discussão de Robinson (1993:52). Para o autor, "a noção de língua minoritária tomou forma através da análise de situações onde a distinção entre maioria e minoria era precisa." No entanto, essa distinção é difusa em muitas situações como em um caso na África que o autor focaliza em sua pesquisa. Além da discussão sobre o conceito de língua minoritária, Hornberger (1998:453) focaliza os conceitos minoria x maioria e afirma que essa distinção está mais relacionada a poder [e prestígio] do que a quantidade (números), ou seja, uma maioria de excluídos significa -poder e -prestígio. Uma minoria de elite tem +poder e +prestígio. Além disso, os termos dão idéia de homogeneidade, escondendo a diversidade e a heterogeneidade dos grupos.
} 
português considerada de baixo prestígio, e, portanto, naturalizadamente invisível (Vide discussão em Bortoni-Ricardo, 1984 e em Bagno, 1997, 1999) e inferiorizada dentro e fora da comunidade.

Os estudos mencionados no parágrafo anterior vêm mostrando escolas oficialmente monolíngües em cenários bilíngües/bidialetais, onde as línguas da comunidade convivem com a língua da escola, muitas vezes de forma imperceptível aos participantes ou de forma não reconhecida pelos mesmos em suas representações sociais ${ }^{30}$ (Fairclough, 1989). Como mencionado, no entanto, ainda se sabe muito pouco sobre essas escolas. Mais estudos são necessários.

Antevejo um ponto de divergência nas representações sociais que as comunidades podem ter sobre a escola e sobre a escrita e suas relações com a discussão atual sobre o letramento (Vide Street, 1993, 1995; Barton, 1994; Soares, 1999; Heath, 1987; Kleiman, 1995). No contexto indígena (Cavalcanti, 1998c), a escola é algo que vem de fora, alheia à educação tradicional dentro da cultura local, mas pode ser algo mais próximo dependendo do contato do grupo com a sociedade envolvente (Ver César, em andamento). Nas escolas em comunidades imigrantes, de fronteira e rurbanas a relação pode ser diferente. Ainda se sabe pouco sobre o assunto.

Em 1987, Zuñiga et alii afirmava que "o cenário em que se processa a Educação Indígena latino-americana é, por um lado, repleto de experiências de extrema riqueza e profundidade, por outro, ele é carente de documentação, e mais ainda de pesquisas científicas". Dado o quadro que é apresentado por Hornberger (1997), o cenário de pesquisa em educação bilíngüe indígena nos outros países da América do Sul não é muito diferente do que dizia Zuñiga et alii (1987). Também não é diferente do que aconteceu no Brasil, uma vez que até o início da década de 90, a maior parte dos trabalhos de pesquisa focalizava a descrição de línguas indígenas. A educação escolar indígena estava, sem dúvida, representada em projetos, porém esses projetos, via de regra, não incluíam pesquisa.

O cenário brasileiro já começou a mudar. De todos os contextos já mencionados, é o indígena que tem merecido maior atenção por parte de

\footnotetext{
${ }^{30}$ Para Fairclough (1989:11): representações são procedimentos de interpretação baseados na liguagem, e conhecimento de mundo das pessoas, suas crenças, seus valores e pressuposições. Ver também Hall (1996) e Cavalcanti (1999b).
} 
pesquisadores, por exemplo, Resende (1992), Ferreira (1992), Carvalho, (1995), Monte (1996), Grillo Guimarães (1996), Cunha (1996), Taukane (1999). É importante registrar que duas dissertações de mestrado vêm de pesquisadoras direta ou indiretamente oriundas de comunidades indígenas. Taukane talvez seja a primeira pesquisadora indígena a olhar seu próprio povo e sua escola. Já Carvalho se autodenomina descendente de Terena e também investiga a educação escolar indígena. Uma parte desses traballhos foi desenvolvida em faculdades de educação e outra parte em departamentos de antropologia. Os trabalhos realizados especificamente na área de Lingüística Aplicada são de Maher (1990, 1996) Mendes (1995, em andamento), César (em andamento), Freitas (em andamento). Maher (1990 e 1996), Rezende (1992), Monte (1994) foram desenvolvidos dentro do Projeto de Autoria, projeto de educação da CPI-Acre. Dois dos cinco trabalhos de tese/dissertação (Maher, 1990 e 1996) que investigaram o cenário do Projeto de Autoria, e mais um, o de Mendes (1995) foram desenvolvidos no Projeto Escolas da Floresta e em seu antecessor (Projeto Guarani). Todos os três trabalhos focalizaram o curso de formação de professores índios de acordo com o objetivo do projeto que os abrigava. Esses trabalhos todos representam um começo. Há necessidade de mais pesquisa. E se há ainda carência de pesquisa em educação escolar indígena, há também no caso das comunidades imigrantes e muito mais há nas comunidades de fronteira e nas comunidades de surdos.

As comunidades imigrantes têm sido examinadas em trabalhos de pesquisa de viés sociolinguístico que tem potencial para trabalhos futuros em LA. Por exemplo, MacRae (1997) focaliza a comunidade britânica em São Paulo, e estende seu interesse para um levantamento das comunidades imigrantes no Estado de São Paulo. Kulczynskyj (1997) vem há tempo investigando a comunidade ucraniana no Paraná. Ambos os pesquisadores são das comunidades pesquisadas. Há ainda dissertações de mestrados, por exemplo, Leme (1984), Barnet-Fürst (1989), que se constituem em trabalhos únicos, de meu conhecimento, sem continuidade. Kreutz (1994) registra três teses realizadas no exterior focalizando a nacionalização das escolas nas comunidades alemãs no sul do Brasil. Não há, no entanto, ainda muitos trabalhos de pesquisa focalizando salas de aula no contexto imigrante. $\mathrm{Na}$ Unicamp, na área de Lingüística Aplicada, há dois trabalhos de pesquisa concluídos, uma dissertação de mestrado (Jung, 1997) e uma tese de doutorado (Pereira, 1999) ambos sobre escolas em comunidades rurais de imigração alemã no Paraná. Há também uma pesquisa focalizando descendentes de japoneses na sala de aula de língua japonesa na universidade (Takasu, 1999). 
Nas regiões de fronteira, o trabalho mais conhecido é o de Trindade, Behares \& Fonseca (1995) sobre escolas na fronteira Brasil-Uruguai. Há também vários trabalhos de pesquisa voltados para a fronteira com o Paraguai: brasiguaios. São, na maioria das vezes, trabalhos de descrição sociolingüística que podem servir de ponto de partida para trabalhos em LA. Há um estudo de Martins (1996) sobre uma comunidade de imigrantes brasileiros no Paraguai. Outro estudo de Santos (1999/UFPr) focalizando crianças brasiguaias em escolas de Foz do Iguaçu. Especificamente no campo da Lingüística Aplicada, há o estudo de Martins (em andamento) que investiga uma comunidade imigrante rural cujos integrantes foram do Paraná para o Paraguai. São descendentes de alemães. Seus filhos vão para a escola pública onde o meio de instrução é o espanhol, tem contato com outras crianças que falam também o Guarani. Em casa, falam o português ou o alemão. Ainda outro estudo, recém-iniciado dentro do Projeto Vozes na Escola, de Pereira (em andamento) focaliza estudantes que moram no Paraguai e estudam em Foz do Iguaçu.

Os estudos sobre a sala de aula com alunos surdos e sobre a educação Zuñiga bilíngüe para surdos são escassos ${ }^{31}$ (Vide, no entanto, Freire, 1998). Talvez a afirmação de et alii (1987) seja aplicável aqui (Ver, ainda, Favorito, 1999.) no sentido de que há descrições de projetos educacionais e essas descrições representam cenários potenciais para pesquisas futuras. O Instituto Nacional de Educação de Surdos/RJ tem contribuído para essa discussão com os vários seminários que já promoveu nesta década. Os anais de congressos sobre educação e surdez e sobre educação especial tanto desse instituto como de outras instituições mostram também que há grupos que trabalham com comunidades de surdos que demonstram interesse na área de educação bilíngüe e que uma interlocução (Vide Maher, 1996) entre essas áreas já foi iniciada.

Em relação aos cenários bidialetais, Stella Maris Bortoni-Ricardo (1984, 1988) é pioneira tanto na orientação de estudos (ver, por exemplo, Dettoni, 1995) sobre escolas em comunidades rurais e rurbanas e sobre meninos de rua (Carvalho, 1989) como também na proposta de currículo bidialetal (Bortoni \& Quental, s.d.). Kleiman (1991, 1995) e colaboradoras como Terzi (1995) e Signorini (1992) também têm contribuições relevantes na área.

3 - O cenário sociolingüístico focalizado e a formação de professores: algumas

\footnotetext{
${ }^{31}$ Ver também Gesser (1999) em estudo sobre ouvintes aprendendo LIBRAS com um professor surdo.
} 
implicações

Já na comunidade japonesa, apesar de o programa de ensino ser o mesmo, apareceu a diferença: os alunos eram mais disciplinados, os pais completamente presentes na vida escolar dos filhos, mas o problema da língua dificultava o aprendizado, pois havia alunos que não entendiam uma só palavra em português.

(...) havia o programa a cumprir, as séries misturadas, e a língua como mais um trabalho a cumprir. Na hora do recreio, eu brincava com eles, fazendo os alunos japoneses que falavam o português brincar e falar com aqueles que nada entendiam, para que por meio da brincadeira eles fossem gravando e tomando conhecimento da nossa língua.

D. Lourdes Serrão, professora primária em depoimento realizado em 1992 sobre o final dos anos quarenta no interior do Estado de São Paulo.

Na época em que ser professor era ser respeitado, quando as condições de trabalho eram dignas, quando o professor primário escolhia sua vaga dependendo de classificação em concurso, quando geralmente se começava na zona rural para depois ir se buscar uma posição na zona urbana, a professora Serrão, em suas memórias, recordou a dificuldade enfrentada em sua primeira sala de aula em uma fazenda no interior de São Paulo. A fazenda era parte de uma comunidade imigrante japonesa: os alunos em sala de aula, crianças japonesas que não falavam português, e, havia também alguns poucos alunos filhos de trabalhadores recém-chegados do Nordeste do Brasil. Pode-se imaginar a surpresa dessa professora formada para dar aula no curso primário para falantes nativos de português?

Se o professor (bem) formado para trabalhar nos anos quarenta enfrentava esse quadro sociolingüístico complexo e apelava para sua intuição para trabalhar na situação bilíngüe-bidialetal configurada, imagine-se o que a formação (carente) dos anos oitenta e noventa põe em evidência nos cenários de sala de aula atuais que são principalmente (mas não somente) bidialetais.

Os professores de hoje enfrentam problemas semelhantes aqueles enfrentados pela professora na comunidade japonesa. O contexto sociolingüístico em todos os exemplos acima é sempre complexo e, os cursos de magistério e de Letras não formam professores para enfrentar essas 
realidades. Continuam formando pessoas para trabalhar com o falante nativo ideal em uma comunidade de fala homogênea, sem conflitos ou problemas de qualquer espécie. A escola parece conseguir ficar distante do contexto sóciohistórico e "sobreviver". E isso é suficiente para os tempos atuais de tantas e tão rápidas mudanças? Como já apontei (Cavalcanti, 1999a, entre outros), não vejo a culpa com os professores. Os cursos de formação de professores dentro da conjuntura atual de políticas lingüísticas (muitas vezes não explícitas) e de políticas educacionais devem arcar com essa culpa sobre o status quo. A diversidade lingüística e cultural precisa ser parte da sala da aula, das comunidades envolventes, dos cursos de formação.

Quando focalizo a formação do professor para atuar em contexto bi/ multilíngüe, estou pensando tanto no Curso de Magistério como no Curso de Licenciatura. Estou pensando tanto no professor que no Ensino Fundamental vai trabalhar com múltiplas disciplinas, um trabalho perpassado pelo português e suas variedades em comunidades urbanas, rurbanas e rurais, como no professor que vai trabalhar com a disciplina língua portuguesa em contexto bi/ multilíngüe, bi/multicultural nas mesmas comunidades. Uma vez que a diversidade social e lingüística é apagada e o monolingüismo, naturalizado, parece haver uma justificativa para que não haja questionamento sobre questões várias, por exemplo, a variedade lingüística a ser meio de instrução. Aceita-se como natural que seja o português padrão e nem se cogita na tomada da variedade lingüística familiar ao aluno como ponto de partida. (Ver, no entanto, os trabalhos de Magda Soares, na área de educação, e Stella Maris Bortoni, na sociolingüística educacional.) Aceita-se como natural que todos os alunos compartilhem de uma mesma e única cultura. No entanto, os alunos podem pertencer a grupos culturais diversos, de tradição oral, que são invisibilizados de forma homogeneizante. Por exemplo, usa-se o termo "negros" para fazer referência às comunidades de descendentes de africanos, mas há aí grupos culturais distintos (Ver César, 1995). ( As línguas ancestrais dessas comunidades estão hoje circunscritas principalmente, mas não somente, ao espaço ritual religioso.)

No Curso de Magistério, a Língua Portuguesa é uma disciplina a mais em um currículo que enfatiza a educação geral. Se há nesse currículo um distanciamento da língua, que afinal perpassa todas a matérias dentro das primeiras séries na escola, imagine-se, o distanciamento do ensino de língua dentro de um contexto de diversidade lingüístico-cultural. O Curso de Magistério, segundo os Parâmetros Curriculares Nacionais para o Ensino Fundamental (Versão preliminar, Novembro, 1995), é uma 'habilitação técnica'. 
Há mais de cem habilitações técnicas, o magistério é uma delas. Sendo uma habilitação técnica, cabe ao professor dar a aula e ponto. Em outras palavras, o foco está no "treinamento" e não na formação do profissional da educação.

Os Cursos de Licenciatura de maior prestígio, em muitos casos, se vangloriam por não formar professores. Os professores que acabam indo para as escolas públicas estudam em faculdades particulares pequenas. De qualquer modo, o foco desses cursos é muito mais no conteúdo, deixando a parte pedagógica para os últimos semestres. (Vide Cavalcanti e Moita Lopes, 1991). Disciplinas que seriam essenciais no curso nem fazem parte do currículo, por exemplo, Lingüística Aplicada, Sociolingüística (Educacional), Iniciação à Pesquisa, Antropologia (Educacional), Interação em Sala de Aula. Essas disciplinas poderiam, dependendo de como fossem dadas, sensibilizar os futuros professores para o contexto sociolingüístico complexo que os esperam em muitos dos lugares onde farão sua prática docente.

Nos Cursos de Licenciatura, há um currículo mínimo geralmente concretizado de forma segmentada. Fala-se em integração de conteúdos, mas a segmentação continua. O currículo mínimo é constituído de dois blocos:

·conteúdos específicos

-matérias pedagógicas (estrutura e funcionamento do ensino de Primeiro e Segundo Graus, didática, prática de ensino e psicologia da educação. Normalmente as matérias pedagógicas são cursadas nas Faculdades de Educação ou, como, acontece na maioria dos casos (faculdades particulares), nos institutos onde se deu a formação específica (Letras, Matemática, Geografia, História, Ciências, etc). (Fonte: Parâmetros Curriculares Nacionais para o Ensino Fundamental. Versão preliminar, Novembro, 1995)

Além disso, na concretização desse currículo mínimo existe uma assepsia: o ensino de língua materna sempre voltado para um falante nativo ideal e para uma comunidade de fala homogênea. Essa assepsia não combina com os contextos de educação bilíngüe de minorias.

A questão que aqui se coloca é que os currículos de formação de professores deveriam contemplar uma forma ou outra dos contextos bilíngües/ multilíngües acima mencionados. Para tanto, os currículos devem ter espaço para a discussão de pedagogias culturalmente sensíveis ${ }^{32}$ (Vide Erickson, 1987, Ladson-Billings, 1994, Osborne, 1996). Em outras palavras, não adianta

\footnotetext{
${ }^{32}$ Segundo Ladson-Billings (1994) o conceito de pedagogias culturalmente sensíveis repousa nas seguintes proposições: a) $\mathrm{O}$ aluno deve experienciar o sucesso; b) $\mathrm{O}$ aluno deve manter sua cultura e c) $\mathrm{O}$ aluno deve desenvolver sua consciência crítica.
} 
simplesmente mudar as matérias do currículo. Isso tem que acontecer juntamente com a determinação do perfil do aluno entrante e seu objetivo, com o pressuposto filósofico que faz o tecido do curso, com o entrelaçamento dos objetivos das diferentes disciplinas e do pessoal envolvido.

Os programas de formação de professores deveriam focalizar, através da observação e da iniciação à pesquisa, a diversidade lingüística, uma vez que, como se depreende do que foi exposto, ela é parte dos mais diversos contextos e salas de aula no país. O cenário para várias pesquisas está aí nas salas de aula e suas respectivas comunidades do país. O ponto de partida vem a ser, por exemplo, os vários clichês que se ouvem nas escolas por parte de alunos e professores que podem até explicar esse apagamento dos cenários de bidialetalismo/biculturalismo e também de bi/multilingüismo: "não sabe/não sei nem falar português direito", "falam gozado"/"falo diferente deles" (contextos bidialetais e bilíngües), "cometem erros o tempo todo: só escrevem errado", "você fala alguma coisa em sala de aula e é como se estivesse falando sobre algo de outro planeta"/"não entendo o que a professora fala" (bi/ multiculturalidade), "esse r não é do português" (contextos bilíngües/ bidialetais).

Sabe-se pouco ainda sobre as escolas em vários contextos. Sabe-se menos ainda sobre cursos de formação de professores: geralmente, os currículos são construídos com base em currículos anteriores, sem levar em consideração resultados de pesquisas sobre o assunto, assunto esse que merece preocupação, reflexão e pesquisa. A área tanto de ensino/aprendizagem de língua portuguesa está em desvantagem aqui, pois no ensino/aprendizagem de LE o tema vem sendo objeto de investigação há algum tempo. O mesmo acontece, em menor escala, em educação escolar indígena. E o que tem acontecido em relação à formação de professores indígenas pode ajudar a pensar sobre a formação de professores para a escola pública.

Algumas perguntas que tem permeado a construção de currículos de magistério indígena são: Quem é o professor a ser formado? O que contempla o currículo indígena? Em que difere do currículo de magistério não-indígena? Vou responder estas perguntas focalizando o currículo ${ }^{33}$ elaborado pela Comissão Pró-Índio do Acre para os professores índios do Acre e do Sudoeste

${ }^{33}$ O currículo tem dois blocos, formação básica e formação específica e as matérias são: Línguas (Indígenas e Portuguesa) e Literaturas, Matemática, Estudos Sociais, e Ciências na Formação Básica; e Pedagogia, Prática Reflexiva, Estágio Supervisionado, Iniciação à Pesquisa, e Estudo Independente na Formação Específica. Tem ainda duas transversalidades: Temática (três vértices: terra-desenvolvimento sustentado; língua - bil/multilingüismo; cultura-interculturalidade) e Metodológica - (a formação do professor/pesquisador em serviço). 
do Amazonas. O primeiro ponto a ser observado é que o currículo foi elaborado a posteriori e reflete uma prática nos cursos de formação de professores de mais de dez anos de trabalho da CPI-Acre. Uma dessas práticas é a interdisciplinaridade: por exemplo, não há separação entre disciplinas de conteúdo e disciplinas pedagógicas - línguas indígenas, língua portuguesa e metodologia de ensino caminham entrelaçadamente. Quando se trabalha com produção de material didático, isso é feito tanto nas línguas indígenas como em português. Mais um ponto: o professor já está em serviço desde o início do curso e a condição para que ele continue participando é que ele permaneça em serviço. A prática é, portanto, parte integrante do processo. O currículo de magistério indígena é, na verdade, um currículo de formação de 1o. e 2o. graus. Ele contempla a formação do professor desde os primeiros anos de escolarização, pois alguns desses professores foram alfabetizados no início do curso de formação. E um ponto final: o currículo prevê a iniciação do professor em pesquisa.

Faltou especificar quem é o professor em formação. O professor focalizado tem um perfil diferenciado. Além de professor, ele é "agricultor, caçador, [pescador,] extrator [de seringa], produtor, morador de um espaço sócio-geográfico de onde produz e reproduz sua cultura. [Tem ainda] responsabilidade com a construção de alternativas de sobrevivência econômica [auto-sustentada] e com a formação das novas gerações da floresta." (Fonte: Versão preliminar da Proposta Curricular Bilíngüe Intercultural para a Formação de Professores Índios do Acre e do Sudoeste do Amazonas").

Em resumo, poder-se-ia levantar algumas implicações do currículo de magistério indígena para se repensar, principalmente ${ }^{34}$, o Curso de Licenciatura. Nesse repensar, retomando os pontos da discussão anterior, seria necessário direcionar o foco para:

a) o perfil do aluno a ser formado (Nas discussões sobre currículo nas universidades, as horas de cada disciplina parecem ter mais importância do que o perfil do aluno);

b) o aluno como professor ( $\mathrm{O}$ aluno não é visto como futuro professor nem pelos formadores nem por eles próprios. Diferentemente, no curso de magistério indígena, o aluno é tratado como professor mesmo que não vá sêlo. Enquanto está no curso, é professor.)

c) o currículo de Letras: O currículo de Letras é um apanhado de matérias

\footnotetext{
${ }^{34} \mathrm{O}$ curso de magistério está sendo descontinuado. Fica a indagação sobre a modificação a ser feita e suas implicações a médio e longo prazo.
} 
que cumprem o currículo mínimo. Essa matérias aí estão desde o tempo das Belas Letras. Não é hora de mudar? 1999a);

d) a formação de professores com reflexão sobre a prática (Vide Cavalcanti,

e) a necessidade de maior número de pesquisas sobre os cursos de formação de professores

f) o reconhecimento da necessidade de diversidade lingüística e cultural nas escolas no Brasil. ( Nem a língua 2 ensinada como língua estrangeira nas escolas em comunidades imigrantes, por exemplo, tem prioridade na escolha da língua estrangeira? Isto é: espanhol nas regiões de fronteira; alemão, italiano, ucraniano, japonês, holandês, polonês, etc. em comunidades imigrantes de estabelecimento antigo quando a língua não é mais mantida. E quando a língua é mantida, por que não considerar a possibilidade de educação bilíngüe?)

g) a necessidade de mais pesquisas em sala de aula dentro de uma visão antropológica e educacional (Vide Jacob \& Jordan, 1996), sensível à diversidade cultural e lingüística (Vide Hornberger, 1997, 1998).

Evidentemente que os itens acima não esgotam a discussão. Podem ser vistos como pontos de partida para uma reflexão necessária e já tardia.

\section{Considerações Finais}

Neste texto, arranhei apenas a superfície do tema, a ponta do iceberg. Há muitas outras questões a serem desveladas; muitos outros contextos a serem estudados. É necessário também conhecer melhor os contextos que focalizei. Dessa maneira, aprofundando e ampliando o conhecimento e colocando a história do país em evidência, pode-se buscar uma contribuição para efetivar uma política lingüística de inclusão que tenha influência na modificação dos cursos de formação de professores e de técnicos e agentes educacionais. O importante nessa trajetória é rever, repensar e trabalhar as negações e os apagamentos ${ }^{35}$ da diversidade e da diferença (Vide Weeks, 1991, Barth, 1969.) e os preconceitos (Bagno, 1999) decorrentes que são parte integrante do cenário sociohistórico, cultural e lingüístico brasileiro. Essa reflexão e esse trabalho precisa ser visto de modo amplo e integrado nas escolas (professores e agentes educacionais, alunos e suas famílias), nas comunidades e na sociedade envolvente.

Em resumo, os contextos multilíngües, e por extensão, multiculturais, no ${ }^{35} \mathrm{Na}$ imagem construída pelo "senso comum", a Língua Portuguesa sempre foi falada no Brasil. Nessa imagem, apaga-se a Língua Geral ou Nheengatu (de origem tupi) falada no país nos séculos XVII a XX. (Ver, entre outros, Barros, Borges \& Meira, 1996) Apaga-se também a Língua Geral Africana da época colonial. 
Brasil não são minoritários e devem fazer parte da educação de professores. Em outras palavras, é regra entrar em uma sala de aula multicultural/multilíngüe. Exceção seria encontrar uma sala de aula com "falantes nativos ideais" dentro de uma "comunidade de fala homogênea". Conforme apontei anteriormente (Cavalcanti, 1998c), "é mister que se discuta a relação entre bilingüismo/ bidialetalismo e escola(rização)" nesses contextos de minoria ou de maioria numérica sem poder ou prestígio.

Minha insistência em trazer os contextos bidialetais para este texto sobre estudos sobre educação em contextos bi/multilíngües de minorias está pautado na relevância do tema para a formação de professores. Falar sobre educação em contextos bilíngües no Brasil faz parte do presente com o qual nos deparamos a cada momento nas salas de aula da zona urbana e da zona rural, principalmente, pela interface da educação bilíngüe de minorias com o "bidialetalismo" das variedades lingüísticas estigmatizadas. Os contextos que apresentei tem muitos pontos de convergência e espero tê-los mostrado a contento. Há muito que intercambiar e aprender entre os contextos mencionados e outros contextos que ainda não estão estudados. Espero que a reflexão realizada sirva de inspiração para trabalhos de pesquisa futuros que venham a contribuir para a discussão.

Algumas das questões que ficam para esses trabalhos futuros são: A existência de um contexto bilĺngüe justifica (sempre) a necessidade de educação bilíngüe e intercultural? O que se entende por educação bilíngüe? Todo contexto bilìnguie é também intercultural? O que se entende por educação em contextos bi/multilíngües? Por que as línguas de tradição oral não tem espaço na escola? $\mathrm{O}$ professor em contexto bilíngüe necessita de formação específica? A educação em contextos de minorias não está ajudando a cristalizar mitos que geram preconceitos? Como essas perguntas poderiam ser adaptadas a contextos bidialetais? Tendo estas perguntas como pano de fundo e tendo em primeiro plano as vozes (cf. Bakhtin, 1990, Wertsch, 1991, Cazden, 1993) dessas comunidades bi/multilíngües invisíveis, apagadas do mapa, pode-se focalizar (cf. Cavalcanti, 1997a) os cursos de formação de professores como profissionais em preparaçãp para uma realidade muito mais complexa e inserida dentro do contexto sociohistórico atual. Em resumo, o trabalho com o falante de português padrão em comunidades de fala onde não haja conflitos ou problemas constitui uma fantasia, alimentada implícita ou explicitamente pela negação das línguas (indígenas, africanas, de imigrantes, de sinais) e das variedades do português do Brasil e pelo apagamento dessas comunidades bilíngües pela sociedade, pela elite, pelos escolarizados, pela mídia... 
REFERÊNCIAS BIBLIOGRÁFICAS

Azcona, J. (1993) Antropologia II - A Cultura. Petrópolis: Vozes.

Bакнтіn, M. (1990) Marxismo e Filosofia da Linguagem. $5^{\text {a }}$ ed. São Paulo: Hucitec.

Bagno, M. (1997) A Língua de Eulália: Novela sociolingüística. São Paulo: Editora Contexto.

(1999) Preconceito Lingüístico: O que é, como se faz. São Paulo: Edições Loyola.

BÄRNERT-FÜRST, U. (1989) Manutenção e mudança lingüística no Município de Panambi: Um estudo qualitativo e quantitativo. Dissertação de Mestrado inédita. Unicamp.

Barros, M.C.D.M., L.C. Borges \& M. Meira (1996) A Língua Geral como identidade construída. Revista de Antropologia, 39/1:191-220.

BARTH, F. (org.) (1969) Ethnic groups and boundaries: the social organization of cultural difference. Boston: Little, Brown \& Co.

Barton, D. (1994) Literacy: An Introduction to the Ecology of Written Language. Oxford: Blackwell.

Behares, L.E. (1982) Diglosia em la sociedad escolar de la frontera uruguaya com Brasil. Matriz social del bilingüismo. Cadernos de Estudos Lingüísticos, 6: 228-234.

Bortoni-Ricardo, S.M.B. (1984) Problemas de comunicação interdialetal. Revista Tempo Brasileiro, 78/79: 9-32.

(1985) The Urbanization of Rural Dialect Speakers: A Sociolinguistic Study in Brazil. Cambridge.

(1988) Situações dialógicas assimétricas: implicações para o ensino. Trabalhos em Lingüística Aplicada, 18: 39-60.

(1998) A análise do português brasileiro em três continua: o continuum rural-urbano, o continuum oralidade-letramento e o continuum de monitoração estilística in S. Grosse \& K. Zimmermann (orgs.) Frankfurt: TFM.

Bortoni, S.M. \& L. Quental (s.d) Currículo bidialetal de Língua Portuguesa para o 1 o Grau. (mimeo)

BRITo, L.F. (1993) Integração social e educação de surdos. Rio de Janeiro: Babel Editora.

Cardoso de Oliveira, R. (1988) A Crise do Indigenismo. Campinas: Editora da Unicamp.

CARRIKER, M.K. (1998) Re)construção de identidades em narrativas na primeira pessoa: casos de bilíngües. Dissertação de Mestrado inédita. UNICAMP. 
Carvalho, M.A. (1989) Tô vivu - Histórias dos meninos de rua. Goiânia: CEGRAF/UFG.

CARVALHO, R.F. de (1995) Subsídios para a compreensão da educação escoalr indígena Terena do Mato Grosso do Sul. Dissertação de Mestrado inédita/ UFSM.

Cavalcanti, M.C. (1990) Projeto Guarani: Educação Bilíngüe e Bicultural (Currículo e formação de professores. Projeto de Auxílio Integrado a Pesquisa - CNPq 1990-1991, 1991-1992.

(1991) Interação Guarani/não-Guarani: Etnocentrismo naturalizado na questão do silêncio inter-turnos. Trabalhos em Lingüística Aplicada, 18: $101-110$.

(1993) O aspecto sociocognitivo da leitura (pós-alfabetização) em português como segunda língua em contexto indígena. Projeto de Pesquisa. Bolsa Pesquisa CNPq .(1993-1995)

(1993) Escolas da Floresta e a Formação de Professores: Análise de interações transculturais e intraculturais em contexto pedagógico (19931995/1995/1997) Projeto de pesquisa, financiamento FAPESP Proc. No. 1996/4443-7 (1997-1999) Participação: Coordenadora e pesquisadora.

(1996a) Collusion, resistance and reflexivity: Indigenous teacher education in Brazil. Linguistics and Education, 8: 3-16.

(1996b) Conferência de abertura na XII JELI: Políticas linguiísticas no Brasil (Language teaching policies in Brazil: A retrospective analysis). Departamento de Letras/Universidade de São Paulo e APLIESP. 17/05/ 1996.

(1997a) Formação de professores para contextos bilíngües no Brasil. Conferência proferida na Programação da ALAB na 49 ${ }^{a}$ Reunião Anual da SBPC. Belo Horizonte, MG, 18/07/97.

(1997b) O índio e a escola: A linguagem na construção de representações sobre a educação indígena pós-contato. Projeto de Pesquisa (Proc. CNPq 520616/95-2 NV) (1997-1999) Participação: Coordenadora e pesquisadora

(1998a) Escola(rização) em contextos bilíngües: foco no contexto indígena. Trabalho apresentado no simpósio "Bilingüismo e Construção do Conhecimento" no V CBLA (Congresso Brasileiro de Lingüística Aplicada), UFRGS, Porto Alegre, RS, 31/08a 04/09/1998.

(1998b) Review of S.L. MACKAY \& N.H. Horberger (orgs.) (1996) Sociolinguistics and Language Teaching. Language and Education, 12/2:154-157.

(1998c) Relatório parcial de pesquisa do Projeto "Escolas da Floresta" apresentado à FAPESP. (mimeo) 
(1999a) A prática como fonte de projetos de pesquisa para a formação de professores. In: J. C. P. Almeida F (org.) Professores de Língua Estrangeira em Formação. Campinas, SP: Editora Pontes.

(1999b) Representaciones sociales en una práctica de lengua escrita: interacción transcultural en un curso para formación de maestros para escuelas de la región occidental de la selva amazónica en Brasil. In: A.M. Mejía \& L.Tóvar (orgs.) Perspectivas Recientes del Bilingüismo y de la Educación Bilíngue en Colombia. Editora da Universidad del Valle, Cali, Colômbia.

(1999c) Vozes na Escola: Cultura e Identidade em Cenários Sociolingüisticamente Complexos (Implicações para a formação de professores em contextos bilíngües e/ou bidialetais). Projeto $\mathrm{CNPq}$ 520616/95-2, Modalidade Auxílio Integrado à Pesquisa.

(1999d) Entrecruzamento de Vozes e Representações: o professor e a escola na comunidade (Bilingüismo e/ou bidaletalismo em contextos de tradição oral, minoritários ou majoritários com tratamento de minorias). Plano de trabalho/projeto de pesquisa apresentado ao $\mathrm{CNPq}$ na modalidade Bolsa Produtividade (Auxílio Integrado à Pesquisa).

CAVAlCANTI, M.C. \& T. M. MAHER (1993) Interação transcultural na formação do professor índio. In: L. SEKI (org.) Interação Indio/Não-Indio no Limiar do Século XXI. Campinas: Editora da UNICAMP: 217-230.

Cavalcanti, M.C. \& L.P. Moita Lopes (1991) Implementação de Pesquisa na Sala de Aula de Lingua Estrangeira. Trabalhos em Lingüística Aplicada, 17:133-144.

Cazden, C. B. (1993) Vygotsky, Hymes, and Bakhtin: From word to utterance and voice. In: E.A. Forman, N. Minick \& C.A. Stone (orgs.) Contexts for Learning: Sociocultural Dynamics in Children's Development. New York: Oxford Press.

de Certeau, M. (1995) A Cultura no Plural. Campinas: Papirus. (Tradução de obra originalmente publicada em 1993).

CÉSAR, A.L. (1995) Formação de guias e guardiães do Parque São Bartolomeu: a diversidade lingüística em diversas linguagens. Afro-Ásia, 16:135-166. (em andamento) Construção de autoria na formação do professor. Projeto de pesquisa visando tese de doutorado. PPGLA/UNICAMP.

CÉsAr, A.L. \& J. Silva (1992) As políticas de segregação e resistência negra. Revista Internacional de Língua Portuguesa, 7: 89-98.

Comissão Pro-Índio do Acre, Narradores Kaxinawá, Escritores Kaxinawá (s.d.) Shenipabu Miyui - História dos Antigos. Comissão Pró-Índio do Acre. Rio Branco, Acre.

Correio Braziliense, 21/09/97 (Fonte: http://www.maturidade.com.br/saude/ 
antigos/surdez.htm)

CunHA, M.J. (1996) The Yudja of Xingu: Language, literacy and social changes among speakers of an endangered language. $\mathrm{PhD}$ thesis. University of Lancaster.

D’ANGelis, W.R. \& J. MAZZARollo (1981) A migração brasileira para o Paraguai. Cadernos de Justiça e Paz.

Dettoni, R.V. (1995) Interação em Sala de Aula: as crenças e a prática do professor. Dissertação de Mestrado inédita. UnB.

ElizAincín, A.E. (1976) The emergence of bilingual dialects on the BrazilianUruguayan border. IJSL, 9: 123-134.

Elizaincín, A.E., L.E.Behares \& G. Barrios (1987) Nos falemo brasilero. Dialectos Portugueses em Uruguay. Montevideo: Amesur.

ERICKSON, F. (1987) Conceptions of school culture: An overview. Educational Administration Quarterly, 23/4: 11-24.

(1996) Transformation and school success: the politics and culture of educational achievement. In: E.JACOB \& C. JORDAN (orgs.) Minority Education: Anthropological Perspectives. Norwood: ABLEX. (2a edição, $1^{\text {a }}$ edição 1993).

(1997) Culture in society and in educational practices. In: J.A.BANKS \& C.A. McGee Banks (orgs.) Multicultural Education: Issues and Perspectives. Boston: Allyn and Bacon.

FAIRClough, N. (1989) Language and Power. Londres: Longman.

FAVorito, W. (1999) Educação bilíngüe para surdos. III Congresso Brasileiro sobre Educação Especial. Caderno de Resumos. Curitiba/Pr, 20 a 22/05 e 16 a $18 / 06$, Natal/RN.

FERREIRA, M.K.L. (1992) Da origem dos homens à conquista da escrita: um estudo sobre povos indígenas e educação escolar indígena. Dissertação de mestrado inédita. USP

Folha de São Paulo, Caderno Mais! (06/06/1999) Os Novos Brasilianistas "Negócios com a 'raça brasileira' ", 5:7 e "Armadilhas do racismo" 5:5.

FraGA, M.C.S. (1999) O lugar das instruções do livro didático na interação em aula de língua estrangeira. Dissertação de mestrado inédita. UniCAMP.

Freeman, R. (1998) Bilingual Education and Social Change. Clevedon: Multilingual Matters.

FreitAs, D.B.A.P. (1998) Makuxi - como as crianças sentem e usam sua língua tradicional na escola? Projeto de pesquisa visando tese de doutorado. Programa de Pós-Graduação em Lingüística Aplicada/UnicAmP.

Freire, A.F. (1998) A aquisição do português como segunda língua: uma proposta de currículo. Revista Espaço, 9. Rio de Janeiro/INES.

Garcia, O. \& C.BAKer (orgs.) (1995) Policy and Practice in Bilingual 
Education: Extending the Foundations. Multilingual Matters.

GeE, J. P. (1990) Sociolinguistics and Literacies: Ideology in Discourse. Londres: Falmer Press.

Gesser, A. (1999) Teaching and learning Brazilian Sign Language as a foreign language: a microethnographic description. Dissertação de Mestrado inédita, UFSC.

Grillo Guimarães, S.M. (1996) A aquisição da escrita e diversidade cultural a prática dos professores Xerente. Dissertação de Mestrado inédita, Universidade de Brasília.

Grosjean, F. (1982) Life with Two Languages: An Introduction to Bilingualism. Cambridge, Mass: Harvard University Press.

GuimARães, S.M.G. (1996) A aquisição da escrita e diversidade cultural - a prática de professores Xerente. Dissertação de mestrado inédita. UnB.

Hall, S. (1996) Cultural Representations and Signifying Practices. Londres: Sage/Open University Press.

HAMEL, R.E. (1989) Determinantes sociolingüísiticos de la educacción bilíngüe. Trabalhos em Lingüística Aplicada, 12.

HAMEL, R. E. \& M.T. SieRRA (1983) Diglossia y conflicto intercultural: la lucha por um concepto o la danza de los significantes. Boletin de Antropologia Americana, 8: 98-110.

Heath, S.B. (1987) Ways with Words: Language, Life and Work in Communities and Classrooms. Cambridge University Press.

HoRNBERGER, N.H. (1991) Extending enrichment bilingual education: Revisiting typologies and redirecting policy. In: O. Garcia (org.) Bilingual Education Focusschrift in Honor of Joshua A. Fishman. Volume 1. Philadelphia: John Benjamins.

(org.) (1997) Indigenous Literacies in the Americas: Language Planning from the Bottom up. Berlin: Mouton de Gruyter.

(1998) Language policy, language education, language rights: Indigenous, immigrant and international perspectives. Language in Society, 27: 439-458.

JACOB, E. \& C. JoRDAN (orgs.) (1996) Minority Education: Anthropological Perspectives. Academic Press.

JunG, N.M. (1997) Eventos de letramento em uma escola multisseriada de uma comunidade rural bilíngüe (alemão/português). Dissertação de Mestrado inédita. UNICAMP.

(1998) A formação de escolas núcleo em um contexto multilíngüe. Projeto de doutorado aprovado em exame de seleção na UNESP/Assis e naUFRGS.

Kleiman, A. B. (1991) Introdução. E um início: A pesquisa sobre interação e 
aprendizagem. Trabalhos em Lingüística Aplicada, 18: 5-14.

(org.) (1995) Os significados de letramento: uma nova perspectiva sobre a prática social da escrita. Campinas: Mercado de Letras.

Kleiman, A.B., M. C. CavalCanti \& S. M. Bortoni (1992) Considerações sobre o ensino crítico de língua materna. Anais da IX ALFAL. Setor de Publicações, IEL/UNICAMP.

KREUTZ, L. (1994) A escola teuto-brasileira católica e a nacionalização do ensino in T.L. MüLLER (org.) Nacionalização e Imigração Alemã. São Leopoldo: Editora UNISINOS.

KulCZYNSKYJ, W. (1997) The Ukranian language in Brazil: A sociolinguistic study of a bilingual community. Comunicação apresentada no International Symposium on Bilingualism. 09-12/04/97. Newcastle upon Tyne, GB.

Ladson-Billings, G. (1994) The Dreamkeepers: Successful Teachers of African American Children. San Franciso: Jossey-Bass Publishers.

Leme, M.L.A. (1984) A linguagem na comunidade tirolesa da cidade de Piracicaba/SP. Dissertação de Mestrado inédita, Unicamp.

LeSSER, J. (1999) Negotiating National Identity: Immigrants, Minorities, and the Struggle for Ethnicity in Brazil. Duke Universtiy Press.

MACRAE, M. (1997) Language shift in the Anglo-Brazilian Community in São Paulo: Language, Culture and Symbolic Domination. Comunicação apresentada no International Symposium on Bilingualism. 09-12/04/97. Newcastle upon Tyne, GB.

MAHER, T.M. (1990)"Já que é preciso falar com os doutores de Brasília..." Subsídios para o planejamento de curso de português oral em contexto indígena. Dissertação de Mestrado inédita. UNICAMP.

(1996) Ser professor sendo índio: Questões de lingua(em) e identidade. Tese de Doutorado inédita. UNICAMP.

(1997) O dizer do sujeito bilíngüe: aportes da Sociolingüística. Anais do Seminário Desafio e Possibilidades na Educação Bilíngüe para Surdos. Rio de Janeiro: Instituto Nacional de Surdos.

(1998) Português é língua de índio. Bay (A educação escolar indígena em Minas Gerais). Publicação do Programa de Implantação das Escolas Indígenas de Minas Gerais. Secretária da Educação do Estado de Minas Gerais. (págs 40-43).

Maher, T.M. \& M.C.CAVAlCANTI (1995) O Colorido Atlas Lingüístico Acreano. Jornal Página 20, Seção Papo de Índio, Rio Branco, Acre, 23 a 29/07.

Martin-Jones, M. (s.d) Bilingualism and linguistic minorities. Working Paper 12, Centre for Language and Social Life, Lancaster Univerisity.

MARTINS, L. M. (1996) Um estudo sociolingüístico na comunidade dos imigrantes 
brasileiros em Santa Rosa del Monday. Dissertação de Mestrado inédita. UFPr.

(em andamento) $\mathrm{O}$ ensino escolar e as dificuldades de aprendizagem das crianças multilíngües - alemão, português, espanhol - inseridas em escola bilíngüe - espanhol e guarani - em Santa Rosa del Monday, Paraguai, na zona rural - Linha Jacutinga. Projeto de pesquisa visando tese de doutorado. PPGLA/UNICAMP.

Mendes, J.R. (1995) Descompassos na interação professor-aluno na aula de matemática em contexto indígena. Dissertação de Mestrado inédita. UNICAMP.

(em andamento) As práticas de numeramento em uma comunidade indígena. Pesquisa visando tese de doutorado. PPGLA/UNICAMP.

Ministério da Educação e do Desporto (1998) Referencial Curricular Nacional para as Escolas Indígenas. Brasília, DF: MEC/Secretaria da Educação Fundamental.

Ministério da Educação e do Desporto (1995) Parâmetros Curriculares Nacionais para o Ensino Fundamental. Versão preliminar.

Ministério da Educação e do Desporto (1998) Parâmetros Curriculares Nacionais, $5^{\text {a }}$ a $8^{a}$ séries. (1998) Brasília, DF: MEC.

MonTe, N.L. (1996) Escolas da Floresta - Entre o passado oral e o presente letrado: Diários de Classe de Professores Kaxinawá. Rio de Janeiro: Multiletra.

Nobles, M. (no prelo) Shades of Citizenship: Races and Censuses in Modern Politics. Stanford University Press.

Osborne, A.B. (1996) Practice into theory into practice: culturally relevant pedagogy for students we have marginalized and normalized. Anthropology and Education Quarterly, 27/3: 285-314.

Pereira, M.C. (1999a) Naquela comunidade rural, os adultos falam "alemão" e "brasileiro", na escola, as crianças aprendem o português: Um estudo do continuum oral/escrito em crianças de uma classe bisseriada. Tese de Doutorado. UNICAMP.

PereIRA, M.C. (1999b) Um olhar sobre a fronteira: alunos paraguaios bilíngües - espanhol e guarani - que estudam em escolas monolíngües em Foz do Iguaçu, PR. Projeto de pesquisa (mimeo)

Proposta Curricular Bilíngüe Intercultural para a Formação de Professores Índios do Acre e do Sudoeste do Amazonas (Versão preliminar ora sendo revisada). Elaborada pela Equipe de Educação da Comissão Pró-Índio do Acre/CPI-AC.

RaJAGOPALAN, K. (1998) O conceito de identidade em Lingüística: É chegada a hora para uma reconsideração radical. In: I. SignORINI (org.) Lingua(gem) 
e Identidade: Elementos para uma discussão no campo aplicado. FAPESP/FAEP/Unicamp/Mercado de Letras: 21-46.

RESENDE, M.M.S. (1992) El saber indígena, el saber geográfico y la enseñanza de geografia. Tese de Doutorado inédita. Universidad de Barcelona. Barcelona, Espanha.

Ribeiro, D. (1995) O povo brasileiro: A formação e o sentido do Brasil. São Paulo: Companhia das Letras.

Romaine, S. (1995) Bilingualism. $2^{\mathrm{a}}$ edição. Oxford: Blackwell.

RoBINSON, C.D. (1993) Where minorities are in the majority: language dynamics amidst high linguistic diversity. AILA Review 10: Case studies in minority languages. Offsetdrukkerij Ridderprint.

SAnTos, M.E.P. (1999) Fatores de risco para o sucesso de crianças brasiguaias nas escolas de Foz do Iguaçu: Uma abordagem sociolingüística. Dissertação de Mestrado inédita, UFPr.

SignORINI, I. (1992) É conversando que a gente menos se entende: opacidade e transparência na comunicação intercultural em língua materna. Investigações, 2: 133-144.

Signorini, I. \& M. C. CavalCanti (1998) Introdução. In: I. Signorini \& M.C. Cavalcanti (orgs.) Lingüística Aplicada e Transdisciplinaridade. Campinas: Mercado de Letras.

SoARes, M. (1986) Linguagem e Escola: Uma perspectiva social. São Paulo: Editora Ática.

(1999) Letramento: Um tema em três gêneros. Belo Horizonte: Autentica.

Street, B.V. (1993) Introduction: the new literacy studies. In: B. Street (org.) Cross-cultural Approaches to Literacy. Cambridge.

(1995) Social Literacies: Critical Approaches to Literacy in Development, Ethnography and Education. Londres: Longman.

TAKAsu, F. (1999) O 'silêncio' na interação entre descendentes e nãodescendentes na sala de aula de língua japonesa. Dissertação de mestrado inédita. UNICAMP.

Taukane, D. (1999) A História da Educação Escolar entre os Kurâ-Bakairi. Publicação com recursos do Governo do Estado de Mato Grosso, através da Lei de Incentivo à cultura, com o patrocínio da DamatTa Produtos Agropecuários Ltda.

Terzi, S. B. (1995) A oralidade e a construção da leitura por crianças de meios iletrados. In: A.B. KLeIman (org.) Os significados de letramento: uma nova perspectiva sobre a prática social da escrita. Campinas: Mercado de Letras.

Trindade, A.M., L.E.Behares \& M.C.FonseCa (1995) Educação e Linguagem 
em Áreas de Fronteira Brasil-Uruguai. Santa Maria, RS: Editora da UFSM.

WeEks, J.V. (1991) The value of difference. In: J. RutheRFord (org.) Identity, Community, Culture, Difference. Londres: Lawrence \& Wishart.

Weinreich, U. (1968) Languages in Contact. $2^{a}$ edição. The Hague: Mouton (1ª edição: 1953).

WeRTSCH, J.W. (1991) Voices of the Mind. Cambridge: Harvard University Press. Wiley, T.G. (1996) Language Planning and Policy. In: S.L. Mckay \& N.H. Horberger (orgs.) Sociolinguistics and Language Teaching. Cambridge: Cambridge University Press.

ZuÑIgA, M. et alii (orgs.) (1987) Educación en Poblaciones Indígenas: Políticas y Estrategias en America Latina. Santiago de Chile: UNESCO-OREALC. 